\title{
Fisiognomi Imam Syafii dalam Naskah Wirasat Sapii
}

\author{
Nur Fauzan Ahmad \\ Fakultas IlmuBudaya, Universitas Diponegoro \\ fazwan.268@gmail.com
}

\begin{abstract}
The face can reflect the behavior and character of the owner. For that required expertise to read the face or face reading is known as physiognomy. This paper will discuss how to read the face according to Imam Syafii in the book Wirasat Sapii. The theory used is semiotics. The result shows that Imam Syafii who is the founder of the Syafii mazhab is known to have a high feeling, but in particular there is no work of his hunch. Furthermore in Wirasat Sapii stated that there are eight aspects of the premonition to recognize one's character is seen from the shape and color of the limbs, especially in the face. Eight aspects are head, hair, forehead, eyebrows, ears, eyes, nose, and lips.
\end{abstract}

Keywords: premonition, face, physiognomy, Imam Safi'i.

\section{Intisari}

Wajah bisa mencerminkan perilaku dan watak pemiliknya. Untuk itu diperlukan keahlian untuk membaca wajah atau face reading yang dikenal dengan fisiognomi. Tulisan ini akan membahas bagaimana cara membaca wajah menurut Imam Syafii di dalam kitab Wirasat Sapii. Teori yang digunakan adalah semiotika. Hasilnya menunjukkan bahwa Imam Syafii yang peletak mazhab Syafii memang dikenal mempunyai firasat tinggi, namun secara khusus tidak ada karya beliau terkait ilmu firasat. Selanjutnya di dalam Wirasat Sapii dinyatakan bahwa ada delapan aspek ilmu firasat untuk mengenal watak seseorang dilihat dari bentuk dan warna anggota tubuh, khususnya di bagian wajah. Delapan aspek tersebut adalah kepala, rambut, dahi, alis, telinga, mata, hidung, dan bibir.

Kata kunci: firasat, wajah, fisiognomi, Imam Safi'i.

\section{Pendahuluan}

Kepribadian merupakan bagian yang yang penting dalam menciptakan pergaulan. Kepribadian adalah cara berinterkasi yang khas oleh individu terhadap perangsang sosial dan kualitas diri yang dilakukan terhadap segi sosial lingkungannya (Jalaludin, 2012: 212). Saat berinteraksi dan berhubungan dengan orang lain kita memerlukan bertemu muka/ wajahnya karena wajah adalah unsur yang sangat penting dalam komunikasi.Dengan melihat dan mengenali wajahnya kita bisa mengenali kepribadian lawan bicara, bisamempengaruhi tanpa harus menyinggung perasaan lawan. Wajah dianggap sebagai cerminan kepribadian seseorang, karena wajah seseorang merupakan anggota tubuh manusia yang tampak kelihatan dan bisa menunjukkan suasana dan perasaan hati. Para ahli 
sudah lama mempelajari hubungan antara wajah dan kepribadian, sehingga muncul suatu ilmu yang disebut dengan fisiognomi (Susilo, 2014:14). Wajah dapat memberikan banyak informasi tentang suasana hati, kesehatan, temperamen (watak atau sifat), serta status sosial dan ekonomi.

Salah satu baskah kuna Jawa yang membicarakan fisiognomi ini adalah naskah Wirasat Sapii. Naskah ini berwujud tembang macapat. Naskah Wirasat Sapi’i (WS) merupakan naskah yang berisi ilmu firasat pada wajah manusia yang memiliki makna yang diungkapkan oleh Imam Sapi'i. Naskah WS penulis temukan di Perpustakaan Nasional Republik Indonesia di Jakarta dengan nomor panggil naskah $\mathrm{Br}$ 8. Tulisan ini membahas tentang ilmu fisiognomi sebagai mana yang termaktub di dalam naskah Wirasat Sapii.

\section{Fisiognomi}

Fisiognomi berasal dari kata Phisis yang berarti alam dan Gnomon yang berarti penilaian (Susilo, 2014:14). Fisiognomi adalah seni dan ilmu yang digunakan untuk mengenal karakter seseorang dengan melihat wajah atau dikenal dengan Face Reading (Prasetyono, 2012:6). Ilmu ini pertama disusun oleh Aristoteles dengan meniliti hubungan antara ciri fisik individu dengan watak kepribadian.

Ilmu fisiognomi atau membaca wajah ini bermula pada kebudayaan Cina yang berkembang 2000 tahun yang lalu. Para tabib Cina mempergunakannya sebagai diagnosa penyakit. Pengenalan ciri dan perwatakan yang mendalam sangat membantu dalam mendiagnosa penyakit dan memilih terapi yang tepat, sehingga mampu menganalisis kepribadian para pasien. Orang-orang Cina menyakini konsep wajah mampu mempresentasikan energi, kekayaan, karakteristik, dan sifat seseorang. Konsep tersebut akhirnya memunculkan akupuntur, Feng Shui dan Qi Gong. Sekitar tahun 220 SM, seni pembacaan wajah berkembang pesat, sehingga muncul buku-buku yang membahas tentang anatomi tubuh berupa membacaan wajah, seperti: Gunting Emas dan Catat Bambu. Keahlian ini pertama kali digunakan secara luas pada abad ke-6 SM, dan menjadi spesialisasi dari para Taoist (Prasetyono, 2015: 10). Manusia dalam konsep pembacaan wajah Cina terdapat tiga bagian tubuh harus diurai dan dibaca yaitu tubuh fisik, ruh dan jiwamelalui konsep unsur yin-yang. Tubuh adalah bagianyang secara fisik bisa diindera, dilihat, disentuh, bersifat padat dan memiliki bentuk, warna, dan tekstur. Tubuh dikendalikan oleh ruh (spiritual) dan jiwa (mental) yang bersifat abstrak dan bersatu 
dengan tubuh fisik. Sifat-sifat dasar seseorang direfleksikan dalam bentuk fisik, terutama pada wajah. Wajah dipilih sebab menjadi ekspresi jiwa dan keadaan kesehatan seseorang untuk pertama kali untuk dibaca.

Seni membaca wajah untuk pertama kali diperkenalkan oleh filsuf Gui-Gu Tze (481-221 SM) lewat bukunya yang berjudul Xiang Bian Wei Mangyang sampai sekarang digunakan untuk mempelajari fisiognomi di Cina (Prasetyono, 2010: 9). Ilmu fisiognomi dianggap sangat penting di Barat. Para ahli Yunani kuno mempelajari karakter dan sifat melalui bentuk wajah, rambut, anggota tubuh, bahkan suara. Filsuf Yunani Aristoteles dan Hippocrates melihat adanya hubungan ciri fisik seseorang dengan sifat dan kepribadian, setelah itu ditemukan prinsip-prinsip fisiognomi oleh Shakespeare, Milton, Dryden. Prinsip itu disempurnakan oleh Johan Kaspar Lavater yang mampu menemukan ciri-ciri wajah dengan kecenderungan mental pada abad ke-18. Selanjutnya Franz Joseph Gall (abad ke19) mengajukan teori frenologi kontur tengkorak menjadi petunjuk wilayah otak yang berpengaruh dengan mengidentifikasi 27 titik penting. Baru pada tahun 1960, Paul Ekman menemukan konsep bahwa wajah merupakan instrumen yang efesien dalam berkomunikasi, sehingga ditemukan rumus-rumus yang digunakan untuk menginterprersikan wajah. Selanjutnya pada tahun 1930-an Edward Jones seorang hakim asal Los Angeles mengamati gerak mimik wajah perilaku dalam sidang.Jones melakukan penelitian hingga menemukan metode membaca wajah yang lebih mudah. Pada akhirnya Jones menggunakan fisiognomi dalam proses pemilihan juri sidang, sebab ilmu ini bisa digunakan untuk mengembangkan kepribadian, memperbaiki suatu hubungan sampai pengembangan karir. Setelah itu penelitian kembali dilakukan oleh Robert Whiteside, hasil penelitian tersebut mengungkap kecocokan antara kepribadian, hubungan dan karir yang tingkat kecocokannya mencapai 92\% (Susanto, 2012: 2-4). Pada tahun 1950-an William Sheldon menemukan teori somatotypes atau hubungan antara postur tubuh dengan kepribadian. Teori Fisiognomi dikembangkan oleh Edward Jones dalam mengidentifikasi kejahatan seseorang. Setelah itu Robert Whiteside menggunakan Fisiognomi untuk menempatan kerja (Tickle, 2014: 16) . Selain itu, Barbara Robert penulis Face Reading: What Does Your Face Say? Melakukan penelitian, sehingga ditemukan sistem ilmiah untuk memahami karakter seseorang, berupa sembilan puluh ciri yang dapat dianalisa. Kesimpulan dari penelitian tersebut adalah antara pikiran dan tubuh terdapat hubungan 
yang erat, sebab apa yang dialami secara spiritual, emosional dan mental kan terlihat dalam wajah (Susilo, 2014: 16)

Di kalangan Islam muncul tokoh fisiognomi yakni, Imam Fakhruddin Arrazi(1150-1210 M)yang menulis Al Firasah: Daliluka ila Ma'rifah Akhlaq an-Nas wa Thabai'ihim wa ka'annahum Kitabun Maftuh. Beliau menejermahkan kata "firasat" sebagai istilah untuk menyebut penyimpulan keadaan-keadaan batiniah (yang tidak terlihat) berdasarkan pertanda-tanda lahiriyah (yang kasat mata). Beliau membagi teknikteknik mengetahui watak seseorang menjadi enam bagian, di antara yakni Berdasarkan wajah seseorang. Ar-razi membagi perilaku manusia menjadi dua jenis, Pertama, Perilaku alamiah yang didorong oleh watak dan sifat aslinya (thabi'iyah). Kedua, perilaku operan yang berbentuk oleh tuntutan akal dan syari'at (taklifiyah). Pada perilaku pertama mampu dijadikan petunjuk dalam mengetahui watak seseorang. Seperti orang yang sedang marah maka raut mukanya terlihat marah, sehingga seiring berjalannya waktumukanya menjadi terlihat marah terus dengan bentuk tertentu. Maka dia berwatak pemarah (Ar-Razi, 2015: 74)

Pada tahun 1531, John Indagine mempublikasikan sebuah buku mengenai seni meramal. Di sana, ia melukis sejumlah wajah dengan bentuk hidung, mata, dan telinga yang berlainan berikut interpretasinya. Ia juga membuat teori bahwa mata yang bundar dan besar menunjukkan integritas dan kesehatan yang bagus. Sedangkan mata yang kecil dan cekung adalah pertanda iri hati, kedengkian, dan curiga (Susantio, 2017). Pada tahun 1533, Bartolommeo Cocle menerbitkan Compendium of Physiognomy. Cocle mengklaim bahwa mata yang besar dan bundar menunjukkan kemalasan dan plin-plan. Hal ini berbeda jauh dengan pernyataan John Indagine (Susantio, 2017). Berbagai penafsiran telah diberikan mengenai wajah yang bundar, kotak, bujur, besar, kecil, dan lain sebagainya. Ada pula studi mengenai jarak di antara hidung, telinga, dan mata yang menunjukkan sesuatu mengenai seseorang. Bahkan menurut para ahli itu, berbagai bentuk rahang menunjukkan banyak sekali hal.

Menurut Kamus Besar Bahasa Indonesia (1999:) Firasat adalah 1. keadaan yang dirasakan (diketahui) akan terjadi sesudah melihat gelagat: rupanya dia sudah mendapat -bahwa tidak lama lagi polisi akan membekuknya; 2. kecakapan mengetahui (meramalkan) sesuatu dengan melihat keadaan (muka dan sebagainya): menurut -- $k u$, ia adalah orang yang bijaksana;3 pengetahuan tentang tanda-tanda pada badan (tangan dan sebagainya) 
untuk mengetahui tabiat (untung malang dan sebagainya) orang: setengah orang percaya benar kepada ilmu - 4. keadaan muka (mata, bibir, dan sebagainya) yang dihubunghubungkan dengan tabiat orangnya (untuk mengetahui tabiat orang): menilik -- nya orang itu keras hati sebab rambutnya tebal dan kaku.

Di dalam agama Islam orang yang mempunyai firasat disebut $A l$ Mutawasimin yang menurut pengertian ulama yaitu mereka yang mampu mengetahui suatu hal dengan mempelajari tanda-tandanya (Najah, 2016). Ilmu ini sering dikenal dengan ilmu laduni. Ilmu laduni adalah ilmu ma'rifat. Ilmu Ma'rifat (hakikat), yaitu ilmu tentang sesuatu yang ghaib melalui jalan kasyf (wahyu ilham / terbukanya tabir ghaib) atau ru'ya (mimpi) yang diberikan oleh Allah kepada hamba-hambaNya yang mukmin dan shalih. Ilmu kasyf inilah yang dimaksud dan dikenal dengan julukan "ilmu laduni" di kalangan ahli tasawuf. Ilmu ini dapat diperoleh dengan dua cara yaitu Pertama, ilmu yang didapat tanpa melalui tahapan belajar (wahbiy). Kedua, ilmu yang didapat melalui usaha belajar (kasbiy).

Dalil untuk hal ini adalah firman Allah, artinya,"Sesungguhnya pada yang demikian itu benar-benar terdapat tanda-tanda (keuasaan Kami) bagi orang-orang yang memperhatikan tanda-tanda." (QS.Al-Hijr:75). Sebagian ulama mengatakan bahwa ayat ini turun terhadap para ahli firasat. Asal firasat ini adalah kehidupan dan cahaya yang dianugerahkan Allah kepada siapa saja dari para hamba yang dikehendaki-Nya, sehingga hatinya bersinar. Untuk selanjutnya firasatnya tidak akan pernah meleset sebagaimana firman Allah yang lain. (Baca: QS.Al-An'am:122-123).

Dalam pandangan tasawuf, orang yang beriman, bertakwa dan rajin beramal saleh serta dekat dengan Tuhan dengan mengamalkan kesunnahan yang disenangi Tuhan maka Tuhan akan melipahkan Nur-Nya sehingga mempunyai potensi untuk memperoleh firasat ini sebagaimana hadis qudsi berikut.

"Dan tidaklah hamba-Ku bertaqarrub kepada-Ku dengan sesuatu lebih Aku cintai dari apa yang telah Aku wajibkan atasnya, dan senantiasalah hamba-Ku bertaqarrub kepada-Ku dengan amalan-amalan sunnah, hingga Aku mencintainya bila Aku telah mencintainya, maka Aku-lah pendengaran yang dengannya ia mendengar, penglihatan yang dengannya ia melihat, tangan yang dengannya ia memukul, kaki yang dengannya ia berjalan. Dan jika ia meminta kepada-Ku, niscaya Aku pasti memberikannya dan bila ia berlindung kepada-Ku, niscaya aku pasti melindunginya" (HR. Al-Bukhari) 


\section{Mengenal Imam Syafii}

Kitab WS menyebutkan bahwa pengarang kitab ini adalah Imam Sapii atau Imam Syafi'i. Imam Syafii selain dikenal sebagai ahli fikih yang berwibawa pembina madzhab Syafii, ternyata juga seorang yang ahli tentang ilmu firasat. Naskah Wirasat Sapii merupakan karya beliau dalam bidang ilmu membaca wajah seseorang. Di dalam khazanah intelektual Islam, nama Ima Syafi'i sangat terkenal sebagai pembina aliran fiqih atau mazhab Syafi'i. Nama asli Imam Syafi'i adalah Muhammad bin Idris bin Abbas bin Utsman bin Syafi'i Bin Saib Bin Abdu Yazid Bin Hasyim Bin Abdul Muthalib bin Abdi Manaf. Imam Syafi'i adalah berasal dari keturunan arab Quraisy. Nasabnya terkait dengan Nabi Muhammad saw. Beliau lahir di Kota Gaza Palestina pada bulan Rajab 150 Hijrah. Ada yang mengatakan pada malam ia dilahirkan itu Imam Abu Hanifah (Imam Hanafi) meninggal dunia akibat diracun oleh Khalifah Abu Ja'far al-Mansur dari Bani Abbasiyah saat Imam Hanafi berada dalam penjara. Ia dipenjara, disiksa dan dirotan karena tidak mau bekerja sama kepada Khalifah Bani Abbasiyah yang lalim itu dengan menolak tawaran untuk menjadi Hakim kerajaannya.

Karya-karya beliau sangat banyak. Seperti Kitab al-Umm, Kitab Ikhtilaf Abi Hanifah wabni Abi Laila, Kitab Ikhtilaf Ali wa Abdillah bin Mas'ud, Kitab Ikhtilaf Malik was Syafi'i, Kitab Jima'il 'Ilm, Kitab Bayan Faraidhillah, Kitab Shifati Nahyi Rasulillah, Kitab Ibthalil Istihsan, Kitab ar-Radd 'Ala Muhammad bin al-Hasan asy-Syaibany, Kitab Siyaril Auzai (Al Kubiy, 1432 H: 67)

Selain seorang ahli di bidang fiqih, Imam Syafii juga dikenal sebagai ahli firasat. Firasatnya tajam. Firasat adalah kemampuan untuk mengenali sosok dan kepribadian seseorang hanya dengan melihat wajah atau tanda-tanda yang tampak pada dirinya. Syāfi'‘ $\overline{1}$ tertarik untuk mempelajari ilmu firasat ini, beruji coba dengannya, bahkan ia sampai mahir dalam mempraktikkannya. Syāfi'ī mendapatkan ilmu ini sejak kecil, saat ia masih tinggal di dusun. Sementara buku-buku tentang ilmu firasat ia peroleh dari Yaman (Saidan, $t$ t)

\section{Fisiognomi dalam Wirasat Sapii}

Naskah Wirasat Sapi'i adalah naskah Arab-Pegon yang terdapat dalam Katalog Induk Naskah-Naskah Nusantara Jilid 4 Perpustakaan Nasional RI yang disunting oleh T.E. Bahrend, 1998 dengan nomor panggil Br 8 di Jakarta. Naskah WS, berupa buku yang tidak 
bergaris terdiri atas 28 halaman, tetapi ada garis di ujung kanan dan kiri dengan menggunakan pensil. Naskah masih utuh dan sampul masih dalam kondisi baik dan tidak sobek. Pada bagian dalam ada sedikit lubang-lubang kecil, karena di makan serangga pada halaman pertama ada tiga kata tulisan Belanda. Naskah dalam kondisi baik, tulisan masih bisa terbaca.

Teks WS ditulis dalam bentuk tembang macapat yang masing-masing memiliki struktur yang khusus, yakni setiap bait terdiri dari sekian larik, setiap larik terdiri dari sekian suku kata (guru wilangan) dan vokal akhir (guru lagu). Dalam WS terdapat tembang cilik yang terdiri dari pupuh sinom dan pupuh dhandanggula. Pupuh sinom terdiri dari 41 bait dan pupuh dhandanggula terdiri dari 20 bait. Penelitian terfokus pada tembang dhandanggula yang berisi ilmu firasat wajah (fisiognomi).

Karya sastra merupakan sistem tanda yang bermakna yang mempergunakan medium bahasa. Sistem bahasa dan sastra merupakan dua aspek penting dalam semiotik. Bahasa merupakan sistem semiotik tingkat pertama yang sudah mempunyai arti (meaning). Dalam karya sastra, arti bahasa ditingkatkan menjadi makna (significance), sehingga karya sastra ini merupakan semiotik tingkat kedua (Preminger, 1974: 981). Pembacalah yang bertugas untuk memberikan makna tanda-tanda yang terdapat pada karya sastra. Tandatanda itu akan memiliki makna setelah dilakukan pembacaan dan pemaknaan terhadapnya. Sesungguhnya dalam pikiran pembacalah transfer semiotik dari tanda terjadi (Riffaterre,1978: 166)

Untuk mendapatkan makna secara semiotik, pertama kali dapat dilakukan dengan pembacaan heuristik dan hermeneutik (Riffaterre, 1978: 5). Pembacaan heuristik yaitu pembacaan berdasarkan struktur bahasanya atau secara semiotik adalah berdasarkan konvensi sistem semiotik tingkat pertama (first order semiotics) (Pradopo, 2005: 77). Sedangkan pembacaan heuristik merupakan pembacaan tingkat pertama untuk memahami makna secara linguistik yang menangkap arti sesuai dengan teks yang ada, dan diartikan dengan bahasa yang sesuai dengan teks. Untuk bisa menangkap maksudnya pembaca diharuskan mempunyai kompetensi linguistik (Riffatere, 1978: 5)

Naskah WS ini berbentuk tembang macapat yang terikat oleh guru lagu dan guru wilangan dalam sastra Jawa. Dalam teks WS terdapat dua pupuh tembang macapat, yaitu pupuh sinom dan pupuh dhandanggula, yang masing-masing pupuh terdapat beberapa bait atau gatra. Oleh karena itu, dalam proses pembacaan semiotik, penulis melakukan proses 
pembacaan dengan cara membuat pembacaan per bait atau gatra dari masing-masing pupuh, dan dari masing-masing pupuh peneliti melakukan proses pembacaan berulangulang untuk menemukan bait atau gatra yang di dalamnya terdapat makna atau tanda semiotik pada teks WS. Oleh karenanya untuk memperjelas arti kebahasaan, dilakukan pembacaan ulang dengan membuatnya menjadi susunan yang normal. Antara lain dengan cara menambahkan kata penghubung, mengembalikkan susunan kata seperti susunan bahasa secara normatif, memberikan sisipan kata dan kata sinonimnya. Penambahan kata tersebut dilakukan supaya arti menjadi jelas. Dalam pembacaan ini belum diberikan makna sajak atau makna sastra (significance). Oleh karena itu, karya sastra (sajak, puisi) harus dibaca ulang dengan memberikan tafsiran hermeneutik sebagai pembacaan tingkat kedua (Riffaterre, 1987: 6). Dalam pembacaan ini teks dibaca ulang agar teks dapat dimengerti dan dipahami. Untuk memunjukkan makna teks dapat digunakan ekspresi langsung yang berupa majas atau makna kias. Jadi, arti bahasa (meaning) yang merupakan arti harfiah teks yang harus di interpretasikan ke dalam pembacaan hermeneutik untuk mendapatkan makna (significan), yaitu mengungkap dan menjelaskan makna harfiah yang terungkap.

Di dalam naskah Wirasat Sapii ditemukan beberapa aspek ilmu firasat dalam membaca wajah orang khususnya dari rambut, dahi, bibir, kepala, alis, telinga, mata, dan hidung. Hal itu dapat dilihat dari tabel 1 berikut.

Tabel 1. Ciri Wajah dan Tandanya

\begin{tabular}{|c|c|c|c|c|}
\hline No. & $\begin{array}{l}\text { Bagian } \\
\text { Tubuh }\end{array}$ & Ciri & Pertanda & Bukti dan Referensi \\
\hline \multirow[t]{3}{*}{1.} & Kepala & Kepala besar & $\begin{array}{l}\text { Jika orang kepalanya } \\
\text { besar, tandanya memiliki } \\
\text { ingatan yang besar. }\end{array}$ & $\begin{array}{l}\text { Yen wong kang agung sirah } \\
\text { hipun./ Pertandane elingan } \\
\text { kardi/ } \\
(W S \text { halaman } 12 \text {, bait } 3)\end{array}$ \\
\hline & & Kepala kecil & $\begin{array}{l}\text { Kepala yang } \text { kecil } \\
\text { tandanya memiliki budi } \\
\text { pekerti yang sedikit dan } \\
\text { tidak banyak berbicara. }\end{array}$ & $\begin{array}{l}\text { Sirah cilik pertondal cekak } \\
\text { budi nipun./ } \\
\text { Tur tuna ing pamicara./ } \\
\text { (WS halaman } 12, \text { bait } 3 \text { ) }\end{array}$ \\
\hline & & $\begin{array}{l}\text { Kepala } \\
\text { sedang }\end{array}$ & $\begin{array}{l}\text { Kepala yang sedang } \\
\text { tandanya bijaksana dalam } \\
\text { berbudi pekerti dan juga } \\
\text { pandai. }\end{array}$ & $\begin{array}{l}\text { Sirah sedeng tanda } \\
\text { wijaksana ing budi./ } \\
\text { (WS halaman } 12 \text {, bait } 3)\end{array}$ \\
\hline 2. & Rambut & $\begin{array}{l}\text { Rambut } \\
\text { kering dan } \\
\text { kaku }\end{array}$ & $\begin{array}{l}\text { Rambut yang kering dan } \\
\text { kaku tandanya pemberani. }\end{array}$ & $\begin{array}{l}\text { Rambut akas iku tanda } \\
\text { wani./ } \\
\text { (WS halaman 12, bait 4) }\end{array}$ \\
\hline
\end{tabular}




\begin{tabular}{|c|c|c|c|c|}
\hline & & $\begin{array}{l}\text { Rambut } \\
\text { halus }\end{array}$ & $\begin{array}{llr}\text { Rambut } & \text { yang } & \text { halus } \\
\text { tandanya } & \text { penakut } & \text { dan } \\
\text { pemalu. } & & \\
\end{array}$ & $\begin{array}{l}\text { Rambut lemes jerih tan } \\
\text { wirangan./ } \\
(\text { WS halaman } 12 \text {, bait } 4)\end{array}$ \\
\hline & & $\begin{array}{l}\text { Rambut } \\
\text { sedang }\end{array}$ & $\begin{array}{l}\text { Rambut yang sedang } \\
\text { artinya yaitu, rambutnya } \\
\text { mengembang, tandanya } \\
\text { memiliki kemantapan, } \\
\text { dan merupakan manusia } \\
\text { yang penuh dengan budi } \\
\text { pekerti. }\end{array}$ & $\begin{array}{l}\text { Rambut kang sedeng } \\
\text { tegese/lya rambut kang } \\
\text { bakung./Mantep jana jerih } \\
\text { budi./ } \\
\text { (WS halaman } 12 \text {, bait } 4)\end{array}$ \\
\hline & & $\begin{array}{l}\text { Rambut } \\
\text { jarang }\end{array}$ & $\begin{array}{l}\text { Rambut yang jarang } \\
\text { tandanya memiliki budi } \\
\text { yang sedikit. }\end{array}$ & $\begin{array}{l}\text { Rambut kang arang cekakl } \\
\text { budinipun. } \\
\text { (WS halaman 12, bait } 4)\end{array}$ \\
\hline & & Rmbut hitam & 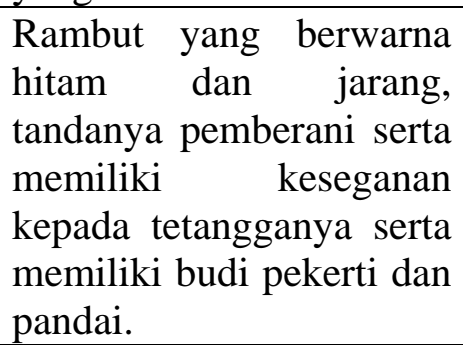 & $\begin{array}{l}\text { Rambut/ ireng kang arang/ } \\
\text { tanda wani. Pakewuh } \\
\text { tongga ning kardi./ Berbudi } \\
\text { tur sujana. } \\
\text { (WS halaman } 12 \text {, bait } 4)\end{array}$ \\
\hline & & $\begin{array}{l}\text { Rambut } \\
\text { kuning }\end{array}$ & $\begin{array}{l}\text { Rambut yang berwarna } \\
\text { kuning tandanya kurang } \\
\text { budi pekerti, bengis dan } \\
\text { mudah marah. }\end{array}$ & $\begin{array}{l}\text { Rambut kuning tonda } \\
\text { akurang budi./ } \\
\text { Alepus tur berangasan } \\
\text { (WS halaman } 12 \text {, bait 5) }\end{array}$ \\
\hline 3. & Dahi & Dahi sempit & $\begin{array}{l}\text { Jika dahi sempit tandanya } \\
\text { memiliki perbuatan yang } \\
\text { budi pekertinya sedikit. }\end{array}$ & $\begin{array}{l}\text { Yen bathuk ciyut watake./ } \\
\text { Akedik budi nipun./ } \\
\text { (WS halaman } 12 \text {, bait } 5 \text { ) }\end{array}$ \\
\hline & & $\begin{array}{lr}\text { Dahi } & \text { yang } \\
\text { lebih } & \text { luas } \\
\text { lagi } & \end{array}$ & $\begin{array}{l}\text { Dahi yang lebih luas lagi } \\
\text { tandanya banyak tidur } \\
\text { dan bengis. }\end{array}$ & $\begin{array}{l}\text { Lewih jembar kebluk tur } \\
\text { bengis./ } \\
\text { (WS halaman 12, bait } 5 \text { ) }\end{array}$ \\
\hline & & $\begin{array}{l}\text { Dahi luas, } \\
\text { rata, dan } \\
\text { tidak } \\
\text { berkerut }\end{array}$ & $\begin{array}{l}\text { Dahi yang luas, rata dan } \\
\text { tidak berkerut tandanya } \\
\text { perasa, berani mengalah, } \\
\text { dan mudah memaafkan. }\end{array}$ & $\begin{array}{l}\text { Bathuk jembar kang ratal } \\
\text { kang ora jangkurawut./ } \\
\text { Iku wateke melas sarsan./ } \\
\text { Wani kalah amomot jembar } \\
\text { kang budi./ } \\
\text { (WS halaman 12, bait 5) }\end{array}$ \\
\hline & & $\begin{array}{l}\text { Dahi } \\
\text { berkerut }\end{array}$ & $\begin{array}{lr}\text { Dahi yang berkerut } \\
\text { melintang di antara bulu } \\
\text { mata, pertanda memiliki } \\
\text { perilaku yang } r \text { tidak } \\
\text { sabaran dan banyak } \\
\text { keprihatinannya. }\end{array}$ & $\begin{array}{l}\text { bathuk jangkeruh } \\
\text { ikaingkang mujur antarane } \\
\text { alis./ } \\
\text { Tanda kereng budi tan } \\
\text { seranta./ Tur akatah } \\
\text { prihatine./ } \\
\text { (WS halaman 12-13, bait 6) }\end{array}$ \\
\hline & & $\begin{array}{l}\text { Dahi } \\
\text { melintang }\end{array}$ & $\begin{array}{lr}\text { Dahi yang } & \text { melintang } \\
\text { tandanya baik dan dalam } \\
\text { perkataannya } & \text { terdapat } \\
\text { kebijaksanaan. } & \end{array}$ & $\begin{array}{l}\text { Dene jangkeruh iku/ } \\
\text { ingkang malang ing bathuk/ } \\
\text { becik tanda (......) limpad. } \\
\text { Wijaksaning tembung./ } \\
\text { (WS halaman } 13 \text {, bait } 6)\end{array}$ \\
\hline
\end{tabular}




\begin{tabular}{|c|c|c|c|c|}
\hline 4. & Alis & Alis lembut & $\begin{array}{l}\text { Alis yang lembut bulunya } \\
\text { tandanya bahwa ia akan } \\
\text { selamat, dalam } \\
\text { permasalahan hati ia } \\
\text { banyak yang menyukai. }\end{array}$ & $\begin{array}{l}\text { Alis kang lembut pertandal } \\
\text { raharjengrat. Ing manah } \\
\text { akayah kang asih./ } \\
(\text { WS halaman } 13 \text {, bait } 6)\end{array}$ \\
\hline & & $\begin{array}{l}\text { Alis agak } \\
\text { kasar }\end{array}$ & $\begin{array}{l}\text { Alis yang agak kasar } \\
\text { tandanya bahwa ia } \\
\text { memiliki sifat pemalas, } \\
\text { tidak suka kalau orang } \\
\text { lain memperoleh } \\
\text { kesenangan, tingkah } \\
\text { lakunya berlebihan, dan } \\
\text { tidak bisa membedakan } \\
\text { mana perbuatan yang } \\
\text { benar dan perbuatan yang } \\
\text { salah. }\end{array}$ & $\begin{array}{l}\text { Alis kang rada kasar.// } \\
\text { Pertanda yen kebluk duweni } \\
\text { bukti./ Akedeb rul alis } \\
\text { (.......)ika. Lumuh kala } \\
\text { wong suko oleh./ Muthokil } \\
\text { rada lengngus./ Tan waruh } \\
\text { ala kalawan becik./ } \\
\text { (WS halaman } 13, \text { bait 6-7) }\end{array}$ \\
\hline & & $\begin{array}{l}\text { Alis agak } \\
\text { menghadap } \\
\text { ke atas }\end{array}$ & $\begin{array}{l}\text { Alis yang agak } \\
\text { menghadap ke atas } \\
\text { tandanya memiliki akhlak } \\
\text { yang mulia, tetapi juga } \\
\text { memiliki perilaku yang } \\
\text { sombong diri, baik buruk } \\
\text { ada dalam hatinya. }\end{array}$ & $\begin{array}{l}\text { Yen wong alise radal } \\
\text { kapareng manduwur./ } \\
\text { Pertanda agung budi nira./ } \\
\text { Tur gumunggungApungguh } \\
\text { dene ta alis./ Sedeng lepas } \\
\text { ing deriya } \\
\text { (WS halaman 13, bait } 7)\end{array}$ \\
\hline 5. & Telinga & $\begin{array}{l}\text { Telinga } \\
\text { kuning }\end{array}$ & $\begin{array}{l}\text { Telinga yang berwarna } \\
\text { kuning tandanya memiliki } \\
\text { budi yang sempurna. }\end{array}$ & $\begin{array}{l}\text { Sampurna budi kuneng ta } \\
\text { kuping } \\
\text { (WS halaman } 13 \text {, bait } 7)\end{array}$ \\
\hline & & Telinga kecil & $\begin{array}{l}\text { Telinga yang ukuranya } \\
\text { kecil tandanya banyak } \\
\text { melakukan perbuatan } \\
\text { yang salah, iri dan keras } \\
\text { kepala. }\end{array}$ & $\begin{array}{l}\text { Yen nana wong ciyut kuping } \\
\text { ira./ } \\
\text { Pertanda akeh salahe./ } \\
\text { Jengkerik panasten besur./ } \\
\text { (WS halaman } 13 \text {, bait } 8)\end{array}$ \\
\hline & & Telinga lebar & $\begin{array}{l}\text { Telinga yang lebar } \\
\text { tandanya memiliki } \\
\text { keselamatan } \\
\text { perilakunya, dalam } \\
\text { memiliki kebodohan yang } \\
\text { berlebihan. }\end{array}$ & $\begin{array}{l}\text { Kuping amba rahayu budi/ } \\
\text { Nanging bodho kalintang./ } \\
\text { Rada kaduk pungkung./ } \\
\text { (WS halaman 13, bait } 8 \text { ) }\end{array}$ \\
\hline & & $\begin{array}{l}\text { Telinga } \\
\text { sedang }\end{array}$ & $\begin{array}{l}\text { Telinga yang berukuran } \\
\text { sedang tandanya bahwa ia } \\
\text { adalah seorang yang } \\
\text { memiliki kehati-hatian } \\
\text { dan perilaku yang } \\
\text { bijaksana. }\end{array}$ & $\begin{array}{l}\text { Kuping } \quad \text { kangsedeng } \\
\text { pertandal } \\
\text { weweka. Bawa leksana } \\
\text { berbudi./ } \\
\text { (WS halaman 13, bait 8) }\end{array}$ \\
\hline 6. & Mata & Mata kecil & $\begin{array}{l}\text { Mata yang berukuran } \\
\text { kecil tandanya memiliki } \\
\text { perilaku baik, agak } \\
\text { khawatiran kalau tingkah } \\
\text { lakunya buruk, dan agak }\end{array}$ & $\begin{array}{l}\text { netra ciyut kalapasan budi./ } \\
\text { Jang ngelatur rada sugih } \\
\text { marasan/ } \\
\text { kang amya ala wateke./ } \\
\text { Lan rada angebluk./ }\end{array}$ \\
\hline
\end{tabular}




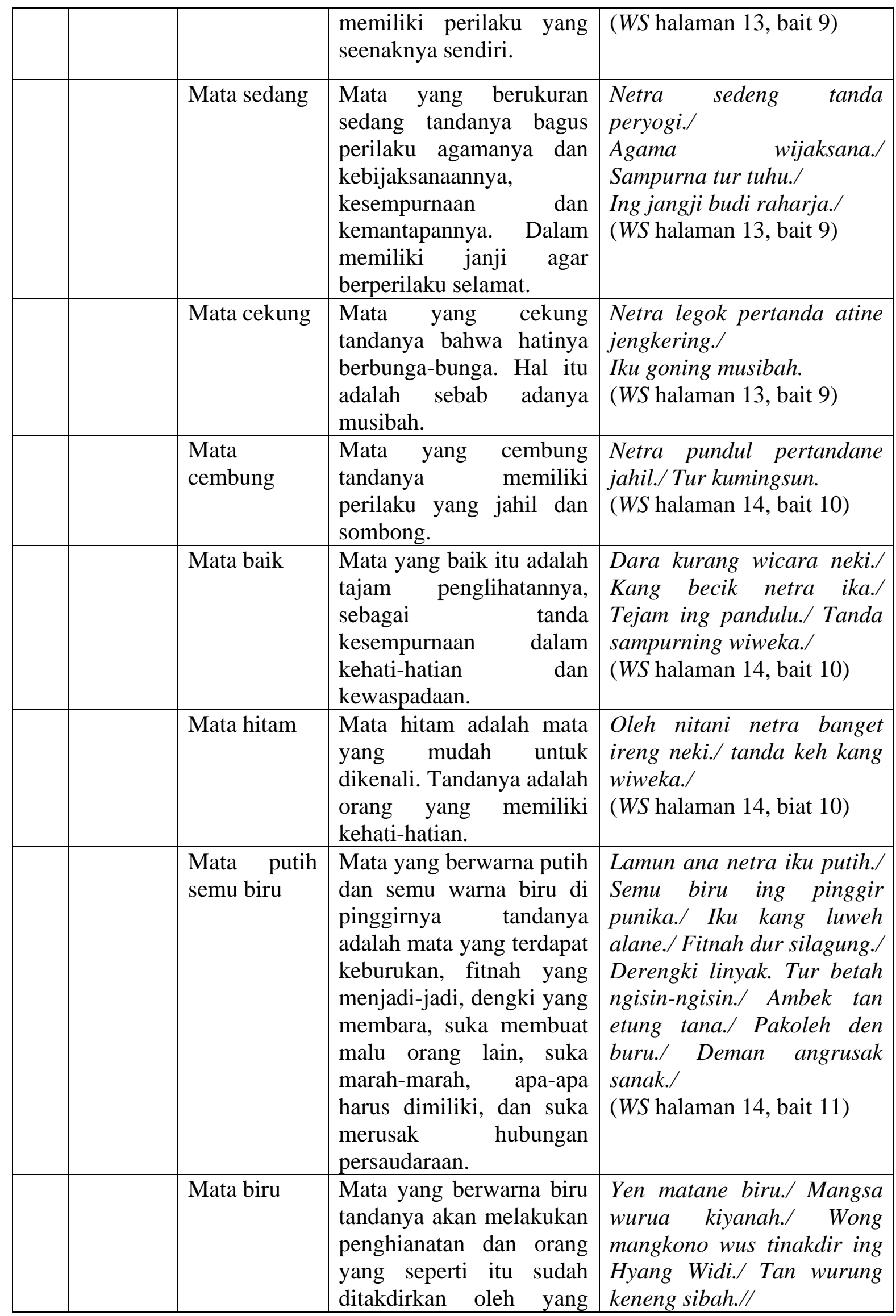




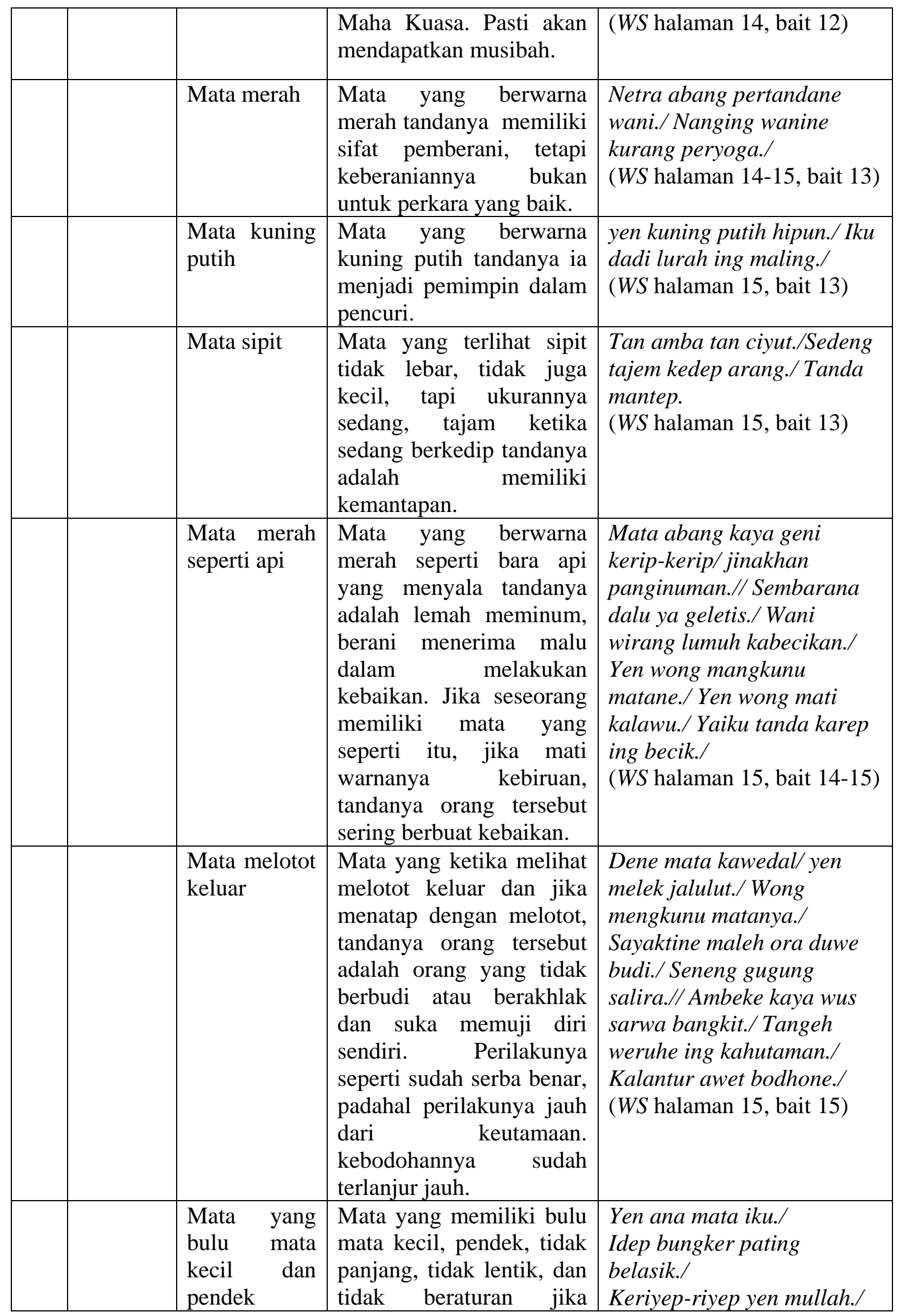




\begin{tabular}{|c|c|c|c|c|}
\hline & & & $\begin{array}{l}\text { memandang tandanya } \\
\text { adalah bencana. }\end{array}$ & $\begin{array}{l}\text { Pertanda bebandu./ } \\
\text { (WS halaman } 15-16 \text {, bait } 16)\end{array}$ \\
\hline & & $\begin{array}{l}\text { Mata yang } \\
\text { jarang } \\
\text { berkedip }\end{array}$ & $\begin{array}{l}\text { Mata yang } \begin{array}{r}\text { jarang } \\
\text { berkedip }\end{array} \\
\text { memiliki tanda krama, } \\
\text { sudah pasti mengetahui } \\
\text { mana perbuatan yang baik } \\
\text { dan mana perbuatan yang } \\
\text { buruk. Orang-orang } \\
\text { politik bosan berbuat } \\
\text { baik. Hukum firasat itu } \\
\text { sudah pasti ada pada } \\
\text { mata. }\end{array}$ & $\begin{array}{l}\text { Mata arang kedepe } \\
\text { pertanda amit/ } \\
\text { pan weruh becik lan ala.// } \\
\text { Para padu lumuh gawe } \\
\text { becik./ } \\
\text { Uger wirasat iku pan mata./ } \\
\text { (WS halaman } 16, \text { bait } 17 \text { ) }\end{array}$ \\
\hline \multirow[t]{6}{*}{7.} & Hidung & $\begin{array}{l}\text { Hidung } \\
\text { panjang }\end{array}$ & $\begin{array}{l}\text { Hidung yang berukuran } \\
\text { panjang } \\
\text { memiliki watak yang } \\
\text { tidak karuan. }\end{array}$ & $\begin{array}{l}\text { Irung kang pinur cita./ } \\
\text { Wong kedawan irung./ } \\
\text { Tanda budine belasar./ } \\
\text { (WS halaman } 16, \text { bait } 18)\end{array}$ \\
\hline & & Hidung tebal & $\begin{array}{l}\text { Hidung yang tebal } \\
\text { tandanya adalah memiliki } \\
\text { banyak pengalaman. }\end{array}$ & $\begin{array}{l}\text { Irung kandel ing antara } \\
\text { kang ireki./ } \\
\text { Tanda sugih carita. } \\
\text { (WS halaman 16, bait 18) }\end{array}$ \\
\hline & & Hidung lebar & $\begin{array}{l}\text { Hidung yang lebar } \\
\text { tandanya suka khawatir. }\end{array}$ & $\begin{array}{l}\text { Irung jembar lang-langan } \\
\text { nireki./ } \\
\text { (WS halaman 16, bait 19) }\end{array}$ \\
\hline & & $\begin{array}{l}\text { Hidung agak } \\
\text { menjorok ke } \\
\text { dalam }\end{array}$ & $\begin{array}{llr}\text { Berhidung } \text { yang } & \text { agak } \\
\text { menjorok ke } & \text { dalam } \\
\text { tandanya adalah } & \text { orang } \\
\text { yang senang } & \text { dalam } \\
\text { bersyahwat. } & \\
\end{array}$ & $\begin{array}{l}\text { Irung kalungsur asih ing } \\
\text { sahwat./ } \\
\text { (WS halaman 16, bait 19) }\end{array}$ \\
\hline & & $\begin{array}{l}\text { Hidung } \\
\text { mancung }\end{array}$ & $\begin{array}{l}\text { Hidung yang mancung } \\
\text { tandanya suka berbohong. }\end{array}$ & $\begin{array}{l}\text { Irung kang jembar } \\
\text { pucuke./Iku tanda gedebus./ } \\
\text { (WS halaman 16, bait 19) }\end{array}$ \\
\hline & & $\begin{array}{l}\text { Hidung } \\
\text { sedang }\end{array}$ & $\begin{array}{l}\text { Hidung yang berukuran } \\
\text { sedang tandanya memiliki } \\
\text { perilaku yang baik. Baik } \\
\text { segala tindakannya. }\end{array}$ & $\begin{array}{l}\text { Irung sedeng pertanda } \\
\text { becik./Becik barangkar } \\
\text { yannya./ } \\
\text { (WS halaman } 16 \text {, bait } 19)\end{array}$ \\
\hline \multirow[t]{2}{*}{8.} & Bibir & Bibir kecil & $\begin{array}{l}\text { Bibir yang kecil tandanya } \\
\text { memiliki watak penakut. }\end{array}$ & $\begin{array}{l}\text { Lambe kang winuwus./ } \\
\text { Lambe ciyut watekira./ Pan } \\
\text { jerihan. } \\
\text { (WS halaman } 16 \text {, bait } 19)\end{array}$ \\
\hline & & Bibir tebal & $\begin{array}{l}\text { Bibir yang tebal di dalam } \\
\text { tandanya memiliki sifat } \\
\text { yang berbudi pekerti, } \\
\text { sombong dan suka } \\
\text { seenaknya sendiri. }\end{array}$ & $\begin{array}{l}\text { Lambe kandhel jero kang } \\
\text { budi./ Gede kaworan } \\
\text { mamak. } \\
\text { (WS halaman 16-17, bait 19) }\end{array}$ \\
\hline
\end{tabular}




\begin{tabular}{|c|c|c|c|c|}
\hline & & Bibir sedang & $\begin{array}{l}\text { Bibir yang berukuran } \\
\text { sedang sudah pasti } \\
\text { tandanya memiliki budi } \\
\text { pekerti yang sempurna. }\end{array}$ & $\begin{array}{l}\text { Lambe sedeng pan } \\
\text { sampurnang budi./ } \\
(\text { WS halaman } 17, \text { bait } 20)\end{array}$ \\
\hline & & Bibir tipis & $\begin{array}{l}\text { Bibir yang tipis tandanya } \\
\text { memiliki sifat untuk } \\
\text { mengingatkan. }\end{array}$ & $\begin{array}{l}\text { lambe tipis wateke elingan./ } \\
\text { (WS halaman } 17 \text {, bait } 20)\end{array}$ \\
\hline & & Bibir biru & $\begin{array}{l}\text { Bibir yang berwarna biru } \\
\text { tandanya suka berbicara } \\
\text { bohong. }\end{array}$ & $\begin{array}{l}\text { Lambe kang biru wateke/ } \\
\text { linnyak Wicara nipun./ } \\
\text { (WS halaman 17, bait } 20 \text { ) }\end{array}$ \\
\hline & & $\begin{array}{l}\text { Bibir } \\
\text { merah }\end{array}$ & $\begin{array}{l}\text { Bibir yang berwarna } \\
\text { semu merah bukan karena } \\
\text { menginang. Sedang } \\
\text { ukuran tipisnya bibir. Hal } \\
\text { tersebut menandakan baik } \\
\text { budi pekertinya } \\
\text { seseorang. }\end{array}$ & $\begin{array}{l}\text { Lambe ingkang asemu } \\
\text { abrih./ } \\
\text { Ora kalawan nginang./ } \\
\text { Sedeng tipisipun./ Pertanda } \\
\text { iku peryoga./ Barang karya } \\
\text { tur ambek rahayu budi. } \\
\text { (WS halaman 17, bait 20) }\end{array}$ \\
\hline
\end{tabular}

(Hikmah, 2017: 121-129)

\section{Simpulan}

Ternyata sejak lama orang sudah menemukan cara membaca sifat seseorang dari wajahnya. Seseorang dapat dilihat dari anggota tubuh, khususnya di bagian wajah, antara lain rambut, dahi, bibir, kepala, alis, telinga, mata, dan hidung. Lewat Wirasat Sapii, Imam Syafi'i menjelaskan dari bentuk dan warna anggota tubuh pada seseorang beserta dengan memberikan masing-masing makna dari tanda ilmu firasatnya.

Ilmu firasat yang terdapat dalam teks WS terdiri dari delapan aspek ilmu firasat mengenai watak seseorang yang dilihat dari bentuk dan warna anggota tubuh, khusunya di bagian wajah. Delapan aspek tersebut adalah (1) Kepala, meliputi: kepala besar, kepala kecil, kepala sedang (2) Rambut, meliputi: rambut kering dan kaku, rambut halus, rambut sedang, rambut jarang, rambut hitam, rambut kuning (3) Dahi, meliputi: dahi sempit, dahi yang lebih luas lagi, dahi luas, rata, dan tidak berkerut, dahi berkerut, dahi melintang (4) Alis, meliputi: alis lembut, alis agak kasar, alis agak menghadap ke atas (5) Telinga, meliputi: telinga kuning, telinga kecil, telinga lebar, telinga sedang (6) Mata, meliputi: mata kecil, mata sedang, mata cekung, mata cembung, mata baik, mata hitam, mata putih semu biru, mata biru, mata merah, mata kuning putih, mata sipit, mata merah seperti api, mata melotot keluar, mata yang bulu mata kecil dan pendek, mata yang jarang berkedip (7) Hidung, meliputi: hidung panjang, hidung tebal, hidung lebar, hidung agak menjorok ke 
dalam, hidung mancung, hidung sedang (8) Bibir, meliputi: bibir kecil, bibit tebal, bibir sedang, bibir tipis, bibir biru, bibir semu merah.

Secara keseluruhan, makna yang terkandung dalam teks WS adalah masing-masing anggota tubuh manusia memiliki makna baik buruknya hati dan wataknya. Ilmu firasat adalah ilmu batin yang tidak dapat dilihat langsung oleh mata manusia, akan tetapi baik buruknya hati, anggota tubuhlah yang berbicara bagaimana perilakunya.

\section{Daftar Pustaka}

Ar-Razi, Imam Fakhruddin. 2015.Kitab Firasat: Ilmu Membaca Sifat dan Karakter Orang dari Bentuk Tubuhnya. Jakarta: Turos.

Departemen Agama, Terjemah Al-Qur" anul karim. Semarang: Alawiyah.

Hikmah, Iis Faridatul, 2017. "Gambaran Watak Manusia Berdasarkan Tanda Pada Wajah Dalam Naskah Wirasat Sapi'i: Suntingan Teks Beserta Analisis Semiotik”. Skripsi pada Jurusan Sastra Indonesia Fakultas Ilmu Budaya Universitas Diponegoro. Semarang.

Irsad, Roxiyul (2016) Bimbingan dan Konseling Islam Pasca Face Readinguntuk Meningkatkan Self Acceptance Calon Istri terhadap Pasangan : Studi Kasus Calon Istri di Biro Konsultasi \& Konseling Keluarga Sakinah AlFalah. Undergraduate Thesis, Uin Sunan Ampel Surabaya.

Jalaluddin. 2012.Psikologi Agama, Jakarta: PT Grasindo.

Tickle, Naomi R. 2014. Cara Membaca Wajah. Jakarta: Ufuk Press.

Pradopo, Rahmat Djoko. 2005. Pengkajian Puisi: Analisis Srata Norma dan Analisis Struktural dan Semiotik. Jogjakarta: Gadjah Mada University Press.

Prasetyono, Dwi Sunar. 2012.Membaca Wajah Orang. Jogjakarta: Diva Press.

Riffaterre, Michael. 1978. Semiotics of Poetry. Blomington: Indiana University Press.

Susantio, Djulianto. 2017. “Fisiognomi Membaca Karakter Lewat Wajah!” artikel tidakdipublikasikan.

Susanto, Iin. 2012. 100 Cara Supercepat Membaca Wajah. Jakarta: Gramedia.

Susilo, Budi, 2014. Membaca Kejujuran dan Kebohongan dari Raut Wajah, Jogjakarta: Diva Press.

Suwaidan, Tariq, tt. Biografi Imam Syafi'iSejarah, Sejarah Para Imam Aswaja. Bandung: Zaman.

Al Kubiy, Sa'aduddin bin Muhammad. 1432 H.Hasyiyah 'ala Al Qoul Al Mukhtar fii Syarh Ghoyatil Ikhtishor. terbitan Maktabah Al Ma'arif Riyadh, cetakan pertama. 